\section{ANALISIS PERILAKU SOSIAL MASYARAKAT DUSUN PLOSOREJO DESA KEMADUH KAB. NGANJUK DALAM TRADISI YASINAN DAN TAHLILAN \\ (Study Deskriptif Melalui Pendekatan Teori Pertukaran Sosial)}

\author{
Oleh: \\ Muhammad Diak Udin*
}

\title{
Abstrak
}

Small Reasarch ini dimaksudkan untuk mendiskripsikan perilaku social masyarakat dusun Plosorejo dalam tradisi yasinan dan tahlilan dengan menggunakan pendekatan teori pertukaran social. Teori pertukaran sosial merupakan bagian dari teori komunikasi interpersonal yang menjabarkan bagaimana seseorang tinggal dan

\section{"IAIT Kediri}


memasuki suatu interaksi sosial dengan mempertimbangkan konsekuensi yang didapatkan dari suatu interaksi interpersonal tersebut. Teori pertukaran sosial memprediksi bahwa nilai dari sebuah hubungan mempengaruhi hasil akhir (outcome) apakah orang akan meneruskan suatu hubungan atau mengakhirinya. Hubungan yang positif biasanya dapat diharapkan untuk bertahan, sedangkan hubungan yang negatif mungkin akan berakhir.

Beradasarkan Small Research ini, penulis dapat mengkategorikan perilaku masyarakat menjadi dua kelompok: Pertama; sebagian masyarakat tetap melestarikan tradisi yasinan dan tahlilan yang dalam istilah teori pertukaran sosial disebut dengan istilah melanjutkan hubungan. Artinya masyarakat merasa bahwa ada keseimbangan antara pengorbanan dan penghargaan yang diterima. Kedua; sebagian masyarakat merasa tidak puas dengan apa yang terjadi di jamiyyah yasin tersebut. Reaksi ini dibuktikan dengan banyak warga yang lebih memilih mengabaiksan dan tidak mengikuti. Dilihat dari kacamata teori pertukaran sosial, perilaku sosial masyarakat dusun Plosorejo yang demikian ini merupakan akibat dari ketidakseimbangan atara pengorbanan dan penghargaan yang diterima.

\section{Keyword: Perilaku Sosial, Teori Pertukaran Sosial}

\section{Pendahuluan}

Komunikasi menjadi bagian yang penting dalam suatu kelompok sosial untuk mengetahui tingkat kepuasan kelompok mereka. Dengan komunikasi seseorang dapat bertukar informasi baik itu kritik ataupun saran. Proses komunikasi dilakukan oleh organisasi atau kelompok sosial dengan tujuan untuk mendapatkan feed back sehingga dapat mencapai pengertian antara anggota masyarakat. Komunikasi sendiri mempunyai banyak tujuan antara lain untuk mendukung identitas diri, membangun kontak sosial dengan orang sekitar, menyelesaikan 
tugas - tugas, memupuk hubungan dengan orang lain. ${ }^{1}$ Dalam suatu hubungan tentunya juga dibutuhkan kepuasan relasi agar seseorang terus bertahan atau tidak dalam hubungan tersebut. Stabilitas relasi dalam teori pertukaran sosial (social exchange theory) dilihat dari pengorbanan dan penghargaan yang diterima untuk dapat bertahan dan mendapatkan kepuasan realasi.

Teori pertukaran sosial merupakan bagian dari teori komunikasi interpersonal yang menjabarkan bagaimana seseorang tinggal dan memasuki suatu interaksi sosial dengan mempertimbangkan konsekuensi yang didapatkan dari suatu interaksi interpersonal tersebut. Teori pertukaran sosial ini dikembangkan oleh Thibaut dan Kelley dapat dipraktikkan dalam konteks komuniukasi interpersonal dan komunikasi kelompok kecil. Teori ini secara umum lebih sering digunakan untuk menganalisis perilaku komunikasi interpersonal.

Menurut Monge dan Contractor Teori Pertukaran Sosial terjadi jika seorang menghitung nilai keseluruhan dari sebuah hubungan dengan mengurangkan pengorbanannya dari penghargaan yang diterima. ${ }^{2}$ Di samping itu di Teori Pertukaran Sosial memprediksi bahwa nilai dari sebuah hubungan memengaruhi hasil akhir (outcome) apakah orang akan meneruskan suatu hubungan atau mengakhirinya, hubungan yang positif biasanya dapat diharapkan untuk bertahan, sedangkan hubungan yang negatif mungkin akan berakhir. ${ }^{3}$

Berdasarkan latar belakang tersebut, peneliti menganggap perlu melakukan Small reaserch untuk mengaplikasikan teori pertukaran sosial dalam dunia nyata. Oleh karena itu, pada kesempatan ini peneliti mencoba memotret

${ }^{1}$ Deddy Mulyana, Ilmu Komunikasi Suatu Pengantar (Bandung : PT. Remaja Rosdakarya, 2007), 4.

${ }^{2}$ Richard West dan Lynn H. Turner, Pengantar Teori Komunikasi: Analisis dan Aplikasi, Terj. Maria Natalia Damayanti (Jakarta: Salemba Humanika, 2008), 216.

${ }^{3}$ Ibid, 217.

Volume 26 Nomor 2 September 2015 
perilaku sosial masyarakat dusun Plosorejo dalam tradisi yasinan dan tahlilan yang didiskripsikan menggunakan pendekatan teori pertukaran sosial. Hal ini dimaksudkan untuk memperoleh jawaban tentang bagaimana perilaku sosial masyarakat dusun Plosorejo desa Kemaduh Kab. Nganjuk dalam tradisi yasinan dan tahlilan yang diselenggarakan pada setiap malam jum'at di rumah-rumah warga.

Pendekatan yang dilaksanakan di dusun Plosorejo Kemaduh Baron Nganjuk menggunakan metode penelitian kualitatif dengan beberapa tahap analisa data yang meliputi; reduksi data, penyajian data dan penarikan kesimpulan (verivikasi

\section{Pembahasan}

\section{Konsep Teori Pertukaran Sosial}

Teori pertukaran sosial di kembangkan oleh John Thibaut dan Harlod Kelley pada tahun 1959. Teori ini memiliki asumsi bahwa orang akan secara sukarela memasuki dan tinggal dalam suatu interaksi sosial dengan mempertimbangkan konsekuensi yang terjadi yaitu untung rugi. Pada dasarnya, dalam membangun sebuah interaksi sosial yang memungkinkan individu untuk memaksimalkan keuntungan yang diperoleh.

Homas mengemukakan bahwa prinsip dasar pertukaran sosial adalah "distributive justice" yaitu suatu aturan yang mengatakan bahwa sebuah imbalan harus sebanding dengan investasi. Dalam teori pertukaran sosial yang menggunakan ekonomi sebagai landasan teorinya bahwa orang berusaha membangun hubungan persahabatan atau percintaan yang hanya akan memberikan keuntungan yang lebih besar.

Sementara West dan Turner menyatakan bahwa Teori Pertukaran Sosial (Social Exchange Theory) di dasarkan pada ide bahwa orang memandang hubungan mereka dalam konteks ekonomi dan mereka menghitung pengorbanan dan 
membandingkannya dengan penghargaan yang di dapatkan dengan meneruskan hubungan itu. Pengorbanan (cost) merupakan elemen dari sebuah hubungan yang memiliki nilai negatif bagi seseorang, sedangkan penghargaan (rewards) merupakan elemen-elemen dalam sebuah hubungan yang memiliki nilai positif. ${ }^{4}$

Sudut pandang Teori Pertukaran Sosial berpendapat bahwa orang menghitung nilai keseluruhan dari sebuah hubungan dengan mengurangkan pengorbanannya dari penghargaan yang diterimanya (Monge \& Contactor, 2003). ${ }^{5}$ Teori Pertukaran Sosial memprediksikan bahwa nilai (worth) dari sebuah hubungan mempengaruhi hasil akhir (outcome) atau apakah orang akan meneruskan hubungan atau mengakhirinya. Hubungan yang positif biasanya dapat diharapkan untuk bertahan, sedangkan hubungan yang negatif mungkin akan berakhir.

Thibault dan Kelley menyimpulkan model pertukaran sosial sebagai berikut: "setiap individu secara sukarela memasuki dan tinggal dalam hubungan sosial hanya selama hubungan tersebut cukup memuaskan ditinjau dari segi ganjaran dan biaya." Ganjaran, biaya, hasil dan tingkat perbandingan merupakan empat konsep pokok dalam teori ini.

\section{Ganjaran}

Ganjaran ialah setiap akibat yang di nilai positif yang diperoleh seseorang dari suatu hubungan. Ganjaran berupa uang, penerimaan sosial atau dukungan terhadap nilai yang di pegangnya. Nilai suatu ganjaran berbeda-beda antara seseorang dengan yang lain, dan berlainan antara waktu yang satu dengan waktu yang lain. Buat orang kaya mungkin penerimaan sosial

${ }^{4}$ Richard West dan Lynn H. Turner, Pengantar Theori Komunikasi: Analisis dan Aplikasi, Terj. Maria Natalia Damayanti (Jakarta: Salemba Humanika, 2008), 216

${ }^{5}$ Ibid.,

Volume 26 Nomor 2 September 2015 
lebih berharga dari pada uang. Buat si miskin, hubungan interpersonal yang dapat mengatasi kesulitan ekonominya lebih memberikan ganjaran dari pada hubungan yang menambah pengetahuan.

\section{Biaya}

Biyaya adalah akibat yang di nilai negatif yang terjadi dalam suatu hubungan. Biaya itu dapat berupa waktu, usaha, konflik, kecemasan, dan keruntuhan harga diri dan kondisikondisi lain yang dapat menghabiskan sumber kekayaan individu atau dapat menimbulkan efek-efek yang tidak menyenangkan. Seperti ganjaran, biaya pun berubah-ubah sesuai dengan waktu dan orang yang terlibat di dalamnya.

\section{Hasil atau Laba}

Hasil atau Laba adalah ganjaran di kurangi biaya. Bila seorang individu merasa dalam suatu hubungan interpersonal, bahwa ia tidak memperoleh laba sama sekali, ia akan mencari hubungan lain yang mendatangkan laba. Misalnya, Anda mempunyai kawan yang pelit dan bodoh. Anda banyak membantunya, tetapi hanya sekedar supaya persahabatan dengan dia tidak putus. Bantuan Anda (biaya) ternyata lebih besar daripada nilai persahabatan (ganjaran) yang Anda terima. Anda rugi. Menurut teori pertukaran sosial, hubungan anda dengan sahabat pelit itu mudah sekali retak dan di gantikan dengan hubungan baru dengan orang lain.

\section{Tingkat Perbandingan}

Tingkat perbandingan menunjukkan ukuran baku (standar) yang dipakai sebagai kriteria dalam menilai hubungan individu pada waktu sekarang. Ukuran baku ini dapat berupa pengalaman individu pada masa lalu atau alternatif hubungan lain yang terbuka baginya. Bila pada masa lalu seorang individu mengalami hubungan interpersonal yang memuaskan, tingkat perbandingannya turun. Bila seorang gadis pernah berhubungan dengan kawan pria dalam hubungan yang bahagia, ia akan 
mengukur hubungan interpersonalnya dengan kawan pria lain berdasarkan pengalamannya dengan kawan pria terdahulu. Makin bahagia ia pada hubungan interpersonal sebelumnya, makin tinggi tingkat perbandingannya, berarti makin sukar ia memperoleh hubungan interpersonal yang memuaskan.

\section{Asumsi Teori Pertukaran Sosial}

Teori Pertukaran Sosial di dasarkan pada metafora pertukaran ekonomis di mana asumsi berangkat dari pemikiran bahwa manusia memandang kehidupan sebagai suatu pasar. Thibaut dan Kelley mendasarkan teori mereka pada dua konseptualisasi ${ }^{6}$ yaitu:

1. Asumsi mengenai sifat dasar manusia

a) Manusia mencari penghargaan dan menghindari hukuman.

Hal ini sesuai dengan konseptualisasi dari pengurangan dorongan (Roloff dalam West \& Turner, 2008: 218). Pendekatan ini berasumsi bahwa perilaku orang dimotivasi oleh suatu mekanisme dorongan internal. Ketika orang merasakan dorongan ini, mereka termotivasi untuk menguranginya, dan proses pelaksanaannya merupakan hal yang menyenangkan.

b) Manusia adalah makhluk rasional.

Teori ini didasarkan pada pemikiran bahwa di dalam batasan-batasan informasi yang tersedia untuknya, manusia akan menghitung pengorbanan dan penghargaan dari sebuah situasi tertentu dan ini akan menuntun perilakunya. Hali ini juga mencakup kemungkinan bahwa, bila dihadapkan pada pilihan yang tidak memberikan penghargaan, orang akan memilih pilihan yang paling sedikit membutuhkan pengorbanan.

\footnotetext{
${ }^{6}$ Ibid, 218.
}

Volume 26 Nomor 2 September 2015 
c) Standar yang digunakan manusia untuk mengevaluasi pengorbanan dan penghargaan bervariasi seiring berjalannya waktu dan dari satu orang ke orang lainnya.

Teori ini mempertimbangkan adanya keanekaragaman. Standar yang digunakan manusia untuk mengevaluasi pengorbanan dan penghargaan bervariasi seiring berjalannya waktu dan dari satu orang ke orang lainnya menunjukkan bahwa teori ini harus mempertimbangkan adanya keanekaragaman. Tidak ada satu standar yang dapat diterapkan pada semua orang untuk menentukan apa pengorbanan dan penghargaan itu.

Thibaut dan Kelley mengambil tiga asumsi mengenai sifat dasar manusia tersebut dari prinsip-prinsip pengurangan dorongan. Dalam pendekatan mereka akan hubungan, mereka menyusun prinsip-prinsip yang mereka sebut sebagai teori permainan (game theory) yang megilustrasikan asumsi pertama mereka disebut dilema seorang tahanan (Prisoner's dilemma). Hasil akhir dari tiap kasus tergantung pada hubungan antar individu, tidak pada satu jawaban saja. Oleh karena itu, ketika seorang partisipan dalam sebuah hubungan mengambil tindakan, baik partisipan yang satu maupun hubungan mereka secara keseluruhan akan terkena akibat.

2. Asumsi mengenai sifat dasar manusia dari suatu hubungan

a) Hubungan memiliki sifat ketergantungan,

b) Kehidupan berhubungan adalah sebuah proses.

Asumsi kedua yang dibuat oleh Thibaut dan Kelley adalah kehidupan hubungan merupakan sebuah proses sehingga waktu dan perubahan dalam kehidupan suatu hubungan menjadi penting. Waktu mempengaruhi pertukaran karena pengalamanpengalaman masa lalu menuntun penilaian mengenai penghargaan dan pengorbanan dan penilaian ini mempengaruhi pertukaran-pertukaran selanjutnya. 


\section{Evaluasi Sebuah Hubungan}

Salah satu bagian yang paling menarik dari teori Thibaut dan Kelley adalah penjelasan mereka mengenai bagaimana orang mengevaluasi hubungan mereka sehubungan dengan apakah mereka akan tetap tinggal dalam hubungan tersebut atau mengabaikannya (meninggalkannya). Thibaut dan Kelley mengklaim bahwa evaluasi ini didasarkan pada dua tipe perbandingan ${ }^{7}$, yaitu:

1. Level Perbandingan (Comparison Level-- CL)

Merupakan standar yang mewakili perasaan orang mengenai apa yang mereka harus terima dalam hal penghargaan dan pengorbanan dari sebuah hubungan.

2. Level Perbandingan untuk Alternatif (Comparison Level for Alternative-CLalt)

Merupakan standar untuk megukur bagaimana orang mengevaluasi sebuah hubungan dibandingkan dengan alternatif realistis dari hubungan tersebut. Hal ini merujuk pada level terendah dari penghargaan dari suatu hubungan yang dapat diterima oleh seseorang saat dihadapkan pada penghargaan yang ada dari hubungan alternatif atau sendirian. Dengan kata lain, CLalt mengukur bagaimana orang mengevaluasi sebuah hubungan dibandingkan dengan alternatif realistis dari hubungan tersebut.

\section{Bagan Teori Pertukaran Sosial}

Secara singkat, bagaimana proses teori pertukaran social bekerja, akan di jelaskan sesuai dengan bagan di bawah ini:

${ }^{7}$ Ibid, 221. 


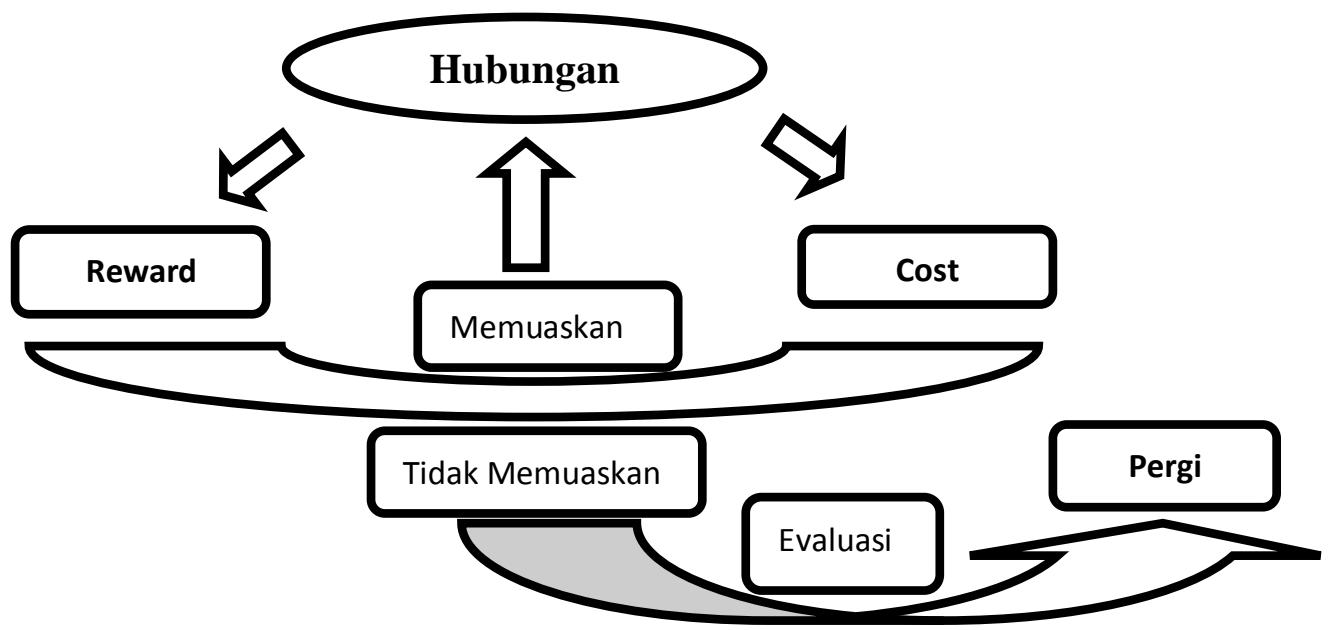

$X \quad$ (di atas CL: hubungan akan bertahan dan lebih dari harapan)

$C L$------ $X$------ (di CL: hubungan akan bertahan dan sesuai harapan)

$X \quad$ (di bawah CL : hubungan akan bertahan namun sangat tidak memuaskan)

\section{Clalt ----- $X$------}

$X \quad$ (di bawah $\mathrm{CL}_{\text {alt: }}$ hubungan akan pergi)

Keterangan :

1. Comparison Level (CL) adalah standar bagi yang mewakili perasaan orang mengenai apa yang mereka harus terima dalam hal reward and cost of relationship.

2. Comparison Level for Alternatives $\left(\mathrm{CL}_{\text {alt }}\right)$ bagaimana orang mengevaluasi suatu hubungan berdasarkan alternatif-alternatif apa yang mereka miliki dari sebuah hubungan.

\section{Yasin dan Tahlil di Plosorejo}

\section{Sejarah Yasinan}

Tradisi yasinan di dusun Plosorejo sebenarnya merupakan tradisi yang terhitung baru. Mulai diselnggarakan 
pada kisaran tahun 1990an. Pada awalnya, muncul sebagai reaksi atas banyaknya warga masyarakat yang menggunakan waktu malamnya untuk sekedar bergadang di warung. Sebagai konsekuensi dari keresahan itu, H. Ahamd Subarri mencoba meminta pertimbangan Kiyai Muhtarom sebagai pemangku salah satu Musholla yang memiliki banyak jama'ah untuk mencari jalan keluar atas kondisi yang dinilainya kurang bermanfaat. Sebagaimana yang diutarakan oleh H. Muhsin;

"Yasinan di dusun Plosorejo ini sebenarnya atas inisiatif bapak saya H. Ahmad Subarri yang melihat banyaknya warga yang habis sholat Isya'malah cangkruk di warung kopi dan ini hampir tiap malam, kan eman-eman kalo begini terus, gak ada nilai ibadahnya. Nah, dari sinilah beliau dan mbah Muhtarom mencoba menggagas adanya jam'iyyah yasinan, ya walaupun satu minggu sekali setidaknya ada nilai ibadahlah, supaya kampong kita ini berkah". 8

Dari perbincangan itulah, maka disepakati diadakan jam'iyyah tahlil dan yasin yang diselenggarakan setiap malam jum'at. Gagasan terbentuknya ide mengganti tradisi bergadang dengan yasinan bisa jadi didasari pada kemiripan kedua aktifitas itu. Bergadang pada malam hari bertujuan untuk mensosialisasikan diri dengan masyarakat serta menambah informasi baru. Sementara pada gagasan tradisi yasinan juga ditujukan pada kedua hal tersebut, hanya ada beberapa tambahan nilai-nilai Islami yang diselipkan di dalamnya. Sehingga ide didirikannya yasinan di Plosorejo sama sekali tidak megubah esensi dan keinginan masyarakat plosorejo yang ingin bersilaturrahim dan mendapat informasi melalui obrolan-obrolan sederhana sekaligus mendapatkan azaz manfaat lain berupa pahala atas bacaan yasin dan tahlil.

${ }^{8}$ Wawancara dengan H. Muhsin, salah seorang anggota jama'ah yang paling senior saat ini pada tanggal 24 Desember 2015.

Volume 26 Nomor 2 September 2015 
Meskipun demikian, ide ini tidak secara langsung diterima di masyarakan dusun Plosorejo yang memiliki kecenderungan bergadang di warung setiap malam. Hal ini tampak pada peserta jam'iyyah yang sangat sedikit. Sebagaimana H. Muhsin menjelaskan; "Pada awalnya, jama'ahnya sedikit, di bawah 10 orang. Ya wajar, ngubah kebiasaan warga itu memang sulit meskipun hanya satu minggu sekali. Tapi lambat laun jama'ahnya bertambah-tambah dan Alhamdulillah sampai hari ini tetap terjaga". 9

Keterangan itu sekaligus mempertegas bahwa proses transformasi ajaran Islam dalam kehidupan masyarakat tidak selamanya berjalan mudah, tetapi membutuhkan waktu dan usaha terus menerus. Untuk mengubah kebiasaan bergadang dengan yang tidak ada nilai ibadahnya dengan tahlilan dan yasinan yang hanya satu malam dalam satu minggu, H. Muhsin dan mbah Muhtarom membutuhkan kegigihan sehingga masyarakat mulai mengikutinya.

\section{Penyelenggaraan dan Susunan Agenda pada acara Tahlil - Yasin}

Sebagaimana telah penulis jelaskan pada subbab terdahulu bahwa tradisi yasinan dan tahlilan di Plosorejo diselenggarakan pada setiap malam jum'at, diadakan bergilir di rumah-rumah anggota. Saat ini, jumlah anggotanya adalah 23 orang yang terdiri dari 5 orang berusia di bawah 35 tahun dan 17 berusia di bawah 60 tahun.

Berdasarkan hasil kesepakatan, acara dimulai setelah jama'ah shalat Isya'di masing-masing Musholla hingga selesainya acara. Standar waktu itulah yang kemudian memberikan ruang bagi terbuangnya waktu, meskipun sebenarnya ada manfaat di balik itu semua. Setelah selesai Jama'ah shalat Isya', para anggota mulai berdatangan satu persatu. Di sela-sela menunggu kedatangan anggota yang lain,

\footnotetext{
${ }^{9}$ Ibid.
} 
biasanya beberapa anggota yang telah datang terlebih dahulu mengadakan perbincangan-perbincangan kecil untuk sekedar shering informsai seputar pertanian dan info-info terbaru di Plosorejo dan sekitarnya. Secara tidak langsung sebenarnya inilah manfaat dari diselenggarakannya yasinan dan tahlilan yaitu menjaga tali silaturrahim dan memberikan pengetahuan baru.

Setelah dirasa cukup untuk di mulai, imam yasinan memberikan kata-kata pembuka dan membacakan susunan leluhur tuan rumah yang hendak dikirim do'a. Kemudian, imam mengajak hadirin untuk beristighfar kepada Allah atas segala kesalahan yang telah diperbuat perbuat.

Secara sederhana penulis akan paparkan susunan agenda jam'iyyah Yasin dan Tahlil di Plosorejo yaitu sebagai berikut; Pertama; Pembacaan tahlil. Imam mulai memimpin dengan memberikan hadiah Fatihah kepada Rasulullah, sahabat, tabi' in dan arwah para anggota tahlil, anggota keluarga yang memiliki hajat dan kemudian arwah para pendiri jam'iyyah yasin Plosorejo. Kemudian rangkain bacaan-bacaan tahlil dibacakan hingga selesai.

Kedua; Istighosah. Pada tahap ini, imam mengajak para anggota untuk membaca istighosah mini yang dibaca dengan nada keras dan bersama-sama. Waktu yang dibutuhkan untuk pembacaan istighosah mini ini adalah sekitar 20 menit.

Ketiga; Pembacaan surat Yasin. Setelelah membaca istoghosah bersama, kemudian para anggota membaca surat yasin sesuai dengan kemampuannya. Ada di antara jama'ah yang mengraskan suara dan ada yang hanya sekedar menggerakkan bibir saja. Meskipun dibaca secara tidak bersamaan, namun biasanya pembacaan surat yasin selesai hampir secara bersamaan. Acara diakhiri dengan pembacaan do'a. Rangkaian pembacan yasin ini biasanya berdurasi sekitar 15 menit. 
Keempat; Pembacaan do'a. Sebagai penutup rangkaian agenda dzikir, kiyai memimpin do'a yang diamini oleh seluruh hadirin dan kemudian do'a di diakhiri dengan membaca surat alFatihah.

Kelima; Pengajian kitab kuning dan tanya jawab. Ada satu agenda tambahan yang membedakan jam'iyyah yasin dan tahlil Plosorejo dengan jam'iyyah serupa di tempat lain yaitu diadakan pengajian kitab kuning. Adalah H. Muhsin yang memimpinnya. Sembari meluruskan kaki dan menengguk suguhan dari tuan rumah, anggota jama'ah mendengarkan penjelasan H. Muhsin tentang materi yang dibawakan. Biasanya pada akhir pembacaan kitab itu, pak Kyai memberikan kesmpatan kepada anggota untuk bertanya. Jika ada yang bertanya, diskusi panjang dilakukan hingga menemukan titik temu. Durasi yang dibutuhkan untuk acara ini berkisar antara 15 hingga 30 menit tergantung materi dan tingkat pemahan anggota.

Jika dianggap telah cukup, acara diakhiri dengan ramahtamah atau sajian makan bersama. Sambil menikmati hidangan, para hadirin biasanya melanjutkan perbincangan pada awal pertemuan tadi. Tidak heran, penulis merasakan ada banyak hal baru yang diperoleh dari proses obrolan yang tampaknya sederhana di majelis dzikir yasin dan tahlil.

\section{Perilaku Sosial Masyarakat dalam Tradisi Yasinan dan Tahlilan}

Berdasarkan hasil amatan peneliti, realitas di dusun Plosorejo desa Kemaduh, Nganjuk saat ini menunjukkan bahwa terjadi kesenjangan minat masyarakat dalam mengikuti majelis dzikir yasinan dan tahlilan. Majelis dzikir yasinan dan tahlil yang diselenggarakan setiap malam Jum'at secara bergiliran di rumah warga memiliki peserta berjumlah 23 orang yang terdiri dari 5 orang berusia di bawah 35 tahun dan 17 berusia di bawah 
60 tahun. Padahal jika melihat banyaknya jumlah penduduk Plosorejo yang mayoritas muslim dan berormas Nahdiyyin, seharusnya jamiyyah tahlilan dan yasinan akan lebih ramai diikuti oleh masyarakat. Banyak di antara mereka yang enggan mengikuti jamiyyah meskipun ada beberapa yang tetap pada pendiriannya untuk tetap mengikutinya.

Sementara itu, teori pertukaran sosial memprediksi bahwa nilai dari sebuah hubungan memengaruhi hasil akhir (outcome) apakah orang akan meneruskan suatu hubungan atau mengakhirinya, hubungan yang positif biasanya dapat diharapkan untuk bertahan, sedangkan hubungan yang negatif mungkin akan berakhir. Realitas di dusun Plosorejo saat ini tampak bahwa sebagian masyarakat tetap melestarikan tradisi yasinan dan tahlilan yang dalam istilah teori pertukaran sosial disebut dengan istilah melanjutkan hubungan. Artinya masyarakat merasa bahwa ada keseimbangan antara pengorbanan dan penghargaan yang diterima.

Dilain pihak sebagian masyarakat merasa tidak puas dengan apa yang terjadi di jamiyyah yasin tersebut. Reaksi ini dibuktikan dengan banyak warga yang lebih memilih mengabaikan dan tidak mengikuti. Dilihat dari kacamata teori pertukaran sosial, perilaku sosial masyarakat dusun Plosorejo yang demikian ini merupakan akibat dari ketidakseimbangan atara pengorbanan dan penghargaan yang diterima.

Berikut ini, peneliti akan mencoba menguraikan hasil penelitian lapangan tentang latar belakang warga Plosorejo yang memilih untuk melanjutkan dan mengabaikan tradisi yasinan dan tahlilan.

\section{Latar Belakang Mengikuti Jam'iyyah}

Meskipun berjumlah puluhan orang, setidaknya jamiyyah yasinan dan tahlilan di Plosorejo masih berjalan hingga saat ini. Mayoritas anggota beranggapan bahwa yasinan dan tahlilan merupakan akulturasi budaya dan ajaran Islam yang 
harus tetap ada dan di lestarikan. Hal ini di dasarkan pada banyak manfaat yang diperoleh dari tradisi tersebut. Sebagaimana pemaparan H. Muhsin pada salah satu diskusi tentang mewabahnya aliran Wahabi di Indonesia. Penuturan yang diutarakan pada diskusi yang lazim dilakukan setelah proses yasinan dan tahlilan berakhir ini berhasil peneliti dokumentasikan sebagai berikut:

"Yasinan dan tahlilan itu adalah amalan yang mulia, ia lahir sebagai perwujadan bahwa Islam itu agama yang rahmatan lil alamin, mampu beradaptasi dengan budaya lokal. Sebagai warga Nahdliyyin, saya dan harusnya seluruh warga Nahdliyyin juga bangga dengan ini". 10

Kemudaian, lebih lanjut pada diskusi itu juga, ada salah satu anggota yang mengutarakan uneg-unegnya serta kekhawatirannya tentang keberlangsungan jam'iyyah yasin dan tahlil yang di masa-masa yang akan datang. Sebagaimana hasil dokumentasi peneliti sebagai berikut:

Jangan sampai, kita termakan oleh pembid'ahan ${ }^{11}$ yang dilakukan oleh kelompok radikal. Jangan dikira yasin dan tahlil itu tidak berdasar, banyak ayat dan hadist yang secara eksplisit menjelaskan tentang itu. Kalau boleh saya katakan, tahlil dan yasinan memang bid'ah tapi bid'ah hasanah yang di dalamnya mengandung banyak manfaat. Jadi kalau bukan kita yang ngramut tradisi ini terus siapa lagi? ${ }^{12}$

Beberapa penuturan di atas jika di analisis menggunakan teori pertukaran sosial, menunjukkan bahwa perilaku sosial

${ }^{10}$ Penuturan H. Muhsin pada tanggal 10 Desember 2015.

${ }^{11}$ Bid'ah adalah segala sesuatu bentuk peribadatan yang tidak pernah diperintahkan ataupun dicontohkan oleh Rasulullah SAW dan atau dikerjakan oleh para sahabat.

12 Penuturan Pak Shodiq pada diskusi yang sama pada tanggal 10 Desember 2015. 
masyarakat dusun Plosorejo yang demikian ini bisa dikategaorikan dengan istilah merasa terpuaskan dengan keberadaaan jamiyyah yasinan dan tahlilan. Keterpuasan itu kemudian mempengaruhi hasil akhir atau keputuasan beberapa anggota untuk tetap mempertahankan dan tinggal di dalamnya.

\section{Latar Belakang Mengabaikan Jam'iyyah}

Majelis dzikir Yasinan di dusun Plosorejo dimulai setelah shalat Isya'. Karena tidak semua warga masyarakat mengikuti rutinitas ini, maka biasanya terjadi tunggu menunggu antara anggota. Dalam situasi seperti ini, sembari menunggu anggota kelompok yang berkisar 25 orang hadir secara keseluruhan, diadakan sharing informasi antar anggota sesuai selera anggota. ada yang membahas tentang pertanian, informasi terbaru dan bahkan agenda politik.

Beberapa testimoni masyarakat tentang jam'iyyah yasin dan tahlil yang enggan mengikuti jam'iyyah mengatakan bahwa waktu yang relative lama mengakibatkan mereka cenderung tidak tertarik mengikutinya. Sebagaimana hasil wawancara peneliti dengan salah satu warga tentang alasan mengapa tidak mengikuti yasinan dan tahlilan malam jum'at? Kemudian informan menjelaskan alasannya sebagai berikut ini:

Kemalaman dimulainya, saya ini petani desa, kerjaannya di sawah, kalau yasinan mulainya jam 20.00 dan selesainya jam 09.00, rasanya sudah ngantuk, enggak kuwat pengen tidur. ${ }^{13}$

Pengakuan hasil wawancara ini memberikan kesan kepada peneliti bahwa waktu yang relative malam membut sebagian orang enggan mengikuti. Hal ini cukup bisa dimengerti karena di wilayah dusun Plosorejo memang mayoritas penduduknya berprofesi sebagai petani atau buruh tani. Biasanya mereka bekerja di sawah mereka atau di sawah orang

${ }^{13}$ Wawancara peneliti dengan pak Jamil, salah seorang Imam di Musolla pada tanggal 06 Desember 2015. 
lain sejak jam 7 pagi hingga sore hari. Rasa letih dan keinginan untuk beristirahat lebih dini kiranya menjadi lazim adanya.

Peneliti mencoba untuk mengembangkan wawancara dengan salah seorang warga yang usianya lebih muda. Pada kesempatan itu, peneliti mendapati bahwa anak-anak muda enggan mengikuti jam'iyyah yasin dan tahlil karena faktor usia dan waktu yang relative lama disbanding dengan kenduri bersama. Sebagaimana yang diungkapkan oleh Eko sebagai berikut; Saya malu mengikutinya (Yasinan dan tahlilan. pen), soalnya mayoritas yang ikut adalah orang-orang tua dan lama banget, mendingan saya buat ngopi sama teman-teman. ${ }^{14}$

Sebagaimana yang telah peneliti sebutkan di atas bahwa memang ada beberapa agenda acara tambahan pada tradisi di jam'iyyah yasin dusun Plosorejo. Setelah pembacaan tahlil, istighosah dan yasinan selesai, biasanya ditambah dengan pembacaan kitab kuning oleh salah seorang kiyai. Pembacaan kitab ini, biasanya diakhiri dengan tany ajawab tentang persoalan yang mungkin belum bisa dipahami oleh anggota. Kebiasaan inilah yang kemudian sedaikit menyebabkan anggota jam'iyyah secara eksplisit tidak menyukainya. Sebagaimana hasil perbincangan peneliti dengan beberapa anggota yang mencoba bertanya, apakah peneliti mengerti tentang pembahasan malam itu; Mas sampeyan paham? Dialognya pakai bahasa Jawa kromo inggil, saya enggak paham, mending langsung pada acara inti (makan-makan. Pen) kelamaan. ${ }^{15}$

Memang pada prosesnya kiyai yang membacakan kitab kuning di pengajian menggunakan bahasa Jawa halus dalam dialognya. Jadi sepanjang pengajian, banyak di antara anggota yang justru sibuk bercanda dan merokok sambil bercerita melanjutkan perbincangan di awal pertemuan.

\footnotetext{
${ }^{14}$ Wawancara peneliti dengan Eko, pada tanggal 08 Desember 2015.

${ }^{15}$ Tanya jawab peneliti dengan salah satu anggota jam'iyyah. 
Dari hasil wawancara di atas memberikan jawaban kepada kita bahwa ketidak puasan masyarakat terhadap penyelenggaraan jam'iyyah yasin dan tahlil menyebabkan mereka mengabaikkan dan tidak mau terlibat di dalamnya. Meminjam istilah teori pertukaran sosial, perilaku sosial masyarakat dusun Plosorejo yang demikian ini akibat dari ketidakseimbangan atara pengorbanan dan penghargaan yang diterima.

\section{Kesimpulan}

Berdasarkan hasil small research tentang Analisis Perilaku Sosial Masyarakat Dusun Plosorejo Desa Kemaduh Kab. Nganjuk dalam Tradisi Yasinan dan Tahlilan yang di deskripsikan melalui pendekatan teori pertukaran sosial yang telah peneliti lakukan, maka peneliti dapat simpulkan ke dalam hal-hal sebagai berikut;

1. tradisi yasinan dan tahlilan di Plosorejo diselenggarakan pada setiap malam jum'at, diadakan bergilir di rumahrumah anggota. Jumlah anggotanya adalah 23 orang yang terdiri dari 5 orang berusia di bawah 35 tahun dan 17 berusia di bawah 60 tahun.

2. Perilaku sosial masyarakat dusun Plosorejo yang diseskripsikan menggunakan teori pertukaran sosial dapat teridentifikasi ke dalam dua kelompok;

a. Sebagian masyarakat merasa puas dengan diselenggaraknnya tradisi yasinan dan tahlilan. Sehingga mereka tetap melestarikan (melanjutkan) dan tinggal di dalam tradisi tersebut. Dalam istilah teori pertukaran sosial, perilaku ini disebabkan oleh keseimbangan antara pengorbanan dan penghargaan.

b. Sebagian besar masyarakat merasa tidak puas dengan diselenggarakannya jamiyyah yasin dan tahlilan, sehingga mereka memutuskan untuk mengabaikannya. 
Meminjam istilah teori pertukaran sosial, perilaku sosial masyarakat dusun Plosorejo yang demikian ini merupakan akibat dari ketidakseimbangan atara pengorbanan dan penghargaan yang diterima. 
Kasiram, Moh. Metodoliogi Penelitian Kualitatif-Kuantitatif. Malang: UIN Maliki Perss, 2008.

Khamad, Dadang. Sosiologi Agama. Bandung: PT. Remaja Rosda Karya, 2009.

Little John, Stephen W \& Karen Foss. Teori Komunikasi. Jakarta: Salemba Humanika, 2011.

Mulyana, Deddy. Ilmu Komunikasi Suatu Pengantar. Bandung :

PT. Remaja Rosdakarya, 2007.

Partanto, Pius \& Dahlan al-barry. Kamus Ilmiah Populer. Surabaya: Arkola, 1994.

Salim, Agus. Teori dan Paradigma Penelitian Sosial. Yogyakarta: Tiara Wacana, 2006.

Walgito, Bimo. Bimbingan dan Penyuluhan di Sekolah. Yogyakarta: Andi Ofset, 1995.

West, Richard dan Lynn H. Turner, Pengantar Teori Komunikasi: Analisis dan Aplikasi. Terj. Maria Natalia Damayanti. Jakarta: Salemba Humanika, 2008. 